\title{
Computation and Assessment of Environmental Emissions Resulting from Traffic Operations at Roundabouts
}

\author{
Göktuğ Tenekeci* \\ ${ }^{1}$ Uluslararası Kıbrıs Üniversitesi, Mühendislik Fakültesi, İnşaat Bölümü, Lefkoşa, KKTC (ORCID: 0000-0003-4177-382X)
}

(This publication has been presented orally at HORA 2019 congress.)

(First received 20 July 2019 and in final form 24 October 2019)

(DOI: $10.31590 /$ ejosat.637594)

ATIF/REFERENCE: Tenekeci, G. (2019). Computation and Assessment of Environmental Emissions Resulting from Traffic Operations at Roundabouts. European Journal of Science and Technology, (Special Issue), 130-145.

\begin{abstract}
Now recognised as a dangerous side effect of increasing human activity and particularly the use of fossil fuels, is the impact on air quality, which has deteriorated considerably in recent times. In particular, the dramatic rise in road traffic has driven up the levels of air pollution in our towns and cities, leading to serious problems for both public health and the environment. To redress this, Environment Policies developed by the World Health Organisation (WHO) and European Commission (EC) have identified clean air as an essential requirement to human health and for the environment - a human right. Therefore, the need for managing emissions resulting from road traffic has seen significant attention. Coincidentally, the increases in the last decades of computational ability has enabled rapid development of transport modelling tools that can be integrated with environmental emissions packages. This has led to the increased ability to test the impact of road emissions on public health and environment. The computational ability to analyse the impact of traffic conditions for both current and forecast operations has enabled engineers to identify improved management and operation techniques for the road intersections with a view to reduce the emissions' impact. This study presents a new and innovative approach to inform such forecast emissions, representing an approach to develop designs that can reduce emissions by linking various software packages as demonstrated at a trial site at a road intersection at Bath, United Kingdom. The technique linked the transport micro-simulation tool VISSIM with the environmental software EnViVer for emissions analysis. The models are also linked to Geographic Information System software, QGIS, to display changing levels of $\mathrm{NOx}, \mathrm{CO}_{2}$ and PM (Particulate Matter) under alternative intersection operational management regimes. This approach has enabled three important outcomes: 1) development of a methodology to directly test emissions and inform air quality thresholds using a series of software tools in an integrated manner, 2) enable the investigation of the air quality outcomes for alternative intersection designs and 3) to produce functions for intersection operational parameters that can predict $\mathrm{NO}_{\mathrm{X}}$, $\mathrm{CO}_{2}$ and PM savings. The results have demonstrated that the linking of the computational ability of micro-simulation modelling of road intersections with environmental package has been successful in analysis of operations. The 'combined' modelling approach has enabled design development of future intersection operation to with a view to minimising $\mathrm{NO}_{\mathrm{X}}, \mathrm{CO}_{2}$ and $\mathrm{PM}$. This approach has brought together the crucial traffic parameters of road speed, delay and queuing and related them directly to change in emissions formulation, with the evidenced based prospect of adoption for similar studies in future. To put numbers to the achievement, the results have shown significant achievements for both the $\mathrm{NO}_{\mathrm{X}}$ level, which is projected to reduce by $14-34 \%, \mathrm{CO}_{2}$ by over $13-32 \%$ and $\mathrm{PM}$ by over $14-26 \%$ compared with the base conditions.
\end{abstract}

Keywords: Computational ability, transport simulation, formulation of emissions.

\section{Computation and Assessment of Environmental Emissions Resulting from Traffic Operations at Roundabouts}

$\ddot{O} \mathbf{z}$

\footnotetext{
* Corresponding Author: Uluslararası Kıbrıs Üniversitesi, Mühendislik Fakültesi, İnşaat Bölümü, Lefokoşa, KKTC, ORCID: 0000-0003-4177-382X, goktug.tenekeci@jacobs.com or Gtenekeci@ciu.edu.tr
} 
İnsan aktivitesinin artması ve fosil yakıtların kullanılması, hava kirliliği oluşumunun başlıca etkenlerindendir. Özellikle karayolu trafik yoğunluğunun dramatik bir şekilde artışı yaşam alanlarımızdaki hava kirliliğinde de artış yaratmakla beraber, hem insan sağlığını hem de çevreyi ciddi şekilde tehlikeye atmaktadır. Bu nedenlerden dolayı Dünya Sağlık Örgütü (WHO - World Health Organisation) ve Avrupa Komisyonu (EC - European Commission) tarafından temiz hava, insan sağlığı ve çevre kirliliğinin önlenmesi için Çevre Politikaları geliştirilmiştir. Bu politikalarla beraber karayolu trafiğinden kaynaklanan emisyonları kontrol altına alınması konusu önemli derecede talep görmüştür. Tesadüfen, son yıllarda hesaplama kabiliyetindeki artış, ulaştırma modelleme araçlarının daha da geliştirilmesi ve çevresel emisyon paketleri ile entegrasyonunu sağlamış ve bununla beraber karayolu emisyonlarının halk sağlı̆̆ ve çevre üzerindeki etkisini test etme becerisi artmıştır. Mevcut ve geleceğe yönelik tahmin edilen operasyonlar için trafik koşullarının etkisini analiz etme yeteneği, mühendislerin emisyonların etkisini azaltmak amacıyla yol kavşaklarında gelişmiş yönetim ve çalışma yapmalarını sağlamıştır. Bu çalışma İngiltere'nin Bath şehrinde bulunan bir yol kavşağını değerlendirmek için çeşitli yazılımları birbirine bağlayarak emisyonları azaltmak ve tasarımlar geliştirmek, tahmini emisyonların bilgilendirilmesi için yeni bir yaklaşım sunmaktadır. Geliştirilen metod çerçevesi, VISSIM ulaşım mikro simülasyon aracını, emisyon analizi için çevre yazılımı olan EnViVer ile ilişkilendirerek elde edilmiştir. Modeller ayrıca alternatif kavşak operasyonel yönetimi için değişen NOx, CO2 ve PM (Partikül Madde) seviyelerini görüntülemek için Coğrafi Bilgi Sistemi yazılımı olan QGIS ile de bağlantılandırılmıştır. Bu yaklaşım üç önemli sonucu ortaya çıkarmıştır: 1) Bir dizi yazılım aracı kullanarak emisyonları test etmek ve hava kalitesi eşiklerini bütünleşik bir şekilde kullanmak için bir metodolojinin geliştirilmesi; 2) Hava kalitesini destekleyen alternatif kavşak tasarımlarının tahmin edilmesi; ve 3) NOX, CO2 ve PM güvenilir fonksiyonların üretilmesi.

Sonuçlar yol kavşaklarının mikro simülasyon modellemesinin çevresel pakete bağlanması için hesaplama yeteneğinin, işlemlerin analizinde başarılı olduğunu göstermiştir. 'Birleşik' modelleme yaklaşımı, NOX, CO2 ve PM'yi en aza indirgemek için gelecekteki kavşak işleminin tasarım geliştirmesini sağlamıştır. Bu yaklaşım, gelecekteki benzer çalışmaların benimsenmesini mümkün kılarak, karayolu hızının, gecikmenin ve emisyon formülasyonundaki değişikliklerin gelişmesine yardımcı olmuştur. Ulaşılan sonuçlara göre, temel koşullarda \% 14-34 azaltması öngörülen NOX, \% 13-32 oranında CO2 ve \%14-26 oranında PM'yi azaltarak önemli başarılar sağlamıştır.

Anahtar Kelimeler: bilgisayar destekli analiz, ulaşım simülasyonu, emisyonların formülasyonu 


\section{Introduction}

The technical analysis of transport network performance and operation has always been fundamental to reduce journey times, improve road intersection capacity, reduce queues, and improve user satisfaction. However, poor network performance not only impacts on traffic operations but also impacts on economic development and is a major contributor to adverse environmental impact. In turn, environmental impact directly relates to Public Health ( $\mathrm{PH})$, a matter now considered highly significant as confirmed by policies set by World Health Organisation (WHO, 2006); and which Member States across Europe are mandated to improve (EC, 2008). With over 400,000 premature deaths every year, alongside other factors, transport related air quality issues have made it the number one environmental cause of premature death in Europe (EEA, 2018).

Coincidentally, the increase in computing power since the early 2000's has enabled further development of transport modelling tools and this can be integrated with environmental emissions packages to assess transport related emissions for current and future predictions of traffic levels and regimes.

Technological advances have supported development of sophisticated micro-simulation tools for road network analysis, can link the outputs to environmental tools and utilise GIS (Geographic Information Systems) to display impact on health and environment. Various tools are available and are documented. This study builds further on the published material that takes the current approaches of using Average Speed Models (ASM) and Instantaneous Emission Models (IEM) related emission calculations to more sophisticated degree of recording. In this study, displacement for each vehicle type with $1 / 5$ fraction of a second on the transport network is modelled, accurately, reflecting each vehicle's movement (i.e. acceleration and deceleration) to inform air quality. The study also utilises real-life data to demonstrate how this model can be a template for future studies in analysing road improvement options from the public health and environmental perspective enhancing the IEM approach.

The computational ability which led to the development of these models now enables us to influence road network design development for the benefit of public health. This can be considered as best use of technology to model transport activity for emissions evaluation on public health and environment.

\section{Environemntal Policies}

The publications of World Health Organisation, European Commission (EC) policies has specified that air quality plans must be developed for cities/zones/districts and agglomerations within which concentrations of pollutants in ambient air exceed the relevant air quality target values or limit values with any temporary tolerance margins as applicable. Therefore, it is required that European Union Member States assess ambient air quality with respect to the pollutants in all their zones and agglomerations (EC, 2008).

The increase in vehicular exhaust emissions due to the dramatic rise in traffic on our roads has contributed to air pollution in our towns and cities, leading to serious problems for both health and the environment. In response, World Heath Organisation (WHO, 2006) has developed Environment Policies followed by the European Commission (EC, 2008) which identified clean air as an essential requirement to human health and for the environment in general. Led by the policies, analysis of vehicle emissions and modelling for current and future years has given rise to the development of environmental tools to analyse emissions.

\section{Traffic Operations and Modelling}

The environmental impact of road intersection operations, particularly during congested conditions imposes not only traffic congestion impact but also significant emissions which threatens public health and our environment. There is a potential role for new design development to contribute towards reducing vehicle emissions and improving local air quality. Key opportunities for this will come through advanced vehicle routing and control functions, and a wider, more strategic approach to demand management, better network designs, mode shift and technological change.

The impacts of the measures may be directly influencing vehicles and users, or indirect in that they facilitate strategic changes in the network. Computational analysis techniques and linking traffic and environmental software with Geographic Information Systems (GIS) enables us to examine impact of current operations, predict emission savings at road intersections, and to develop alternative designs in reducing vehicle emissions. This approach provides a robust platform for evidence base for future decision making around intersection designs (Project Report, 2018).

Since the early 2000 's the increase in computational ability has enabled development of sophisticated modelling tools to a high level of detail which allowed users to display and visualise complex traffic activities in a clear graphical manner. These models, now mostly simulation tools can replicate current operations through calibration and validation processes, whereby allowing confidence in future forecasts to be developed for a multi-modal transport operation (i.e. general-purpose traffic, Heavy Goods Vehicles, bus transit operations, light rail, walking and cycling).

Amongst a selection of modelling tools for traffic, the VISSIM micro-simulation model, due to its high level of detail for each element of transport network, can simulate activities of vehicles and other users in microscopic detail for each vehicle's displacement at fractions of a second during the modelling period. This allows the measurement of acceleration, deceleration and manoeuvring at intersections by replicating interacting traffic behaviour at free-flow and congested conditions. The model can produce a record of each vehicle's movement, delays, queuing profile and associated fuel consumption. It also allows information for vehicle categories for European type approval test for engine types (PTV Vision, 2011).

Utilising outputs from road modelling tools, the emissions modelling can be conducted. There are two approaches:

1) Average Speed Models (ASM)

2) Instantaneous emissions models (IEM)

ASM uses average speed of all vehicles along the network to provide analysis of emissions. It does not have detailed configuration of each vehicle's movement along a congested network. On the other hand, IEM is used to estimate tailpipe emissions from individually 
simulated road vehicles. This enables emissions, based on a range of pollutants including $\mathrm{CO}_{2}, \mathrm{NO}_{\mathrm{X}}$, and $\mathrm{PM}_{10}$, to be estimated for various engine sizes and vehicle types. In contrast to average speed models, IEM importantly captures the variability in vehicle operations and driver behaviours; a crucial factor which is lost in more aggregate models. Despite this relative advantage of the IEM models, neither models are uncapable of assessing cold engine or idling for a longer time which would affect emissions (Fontes et al, 2015).

The organisation of Advanced Science in Delft, Netherlands, has developed the VERSIT+micro suit for the measurement of emissions for traffic conditions. The calculation of emissions for the simulated traffic data emerging from VISSIM enabled traffic engineers and environmental scientists to bring forward analysis of $\mathrm{CO}_{2}, \mathrm{NO}_{\mathrm{x}}$, and $\mathrm{PM}_{10}$ by categories of vehicles. This model uses complex interaction of vehicles for an entire modelling period which enables calculations using velocity-time profiles for each vehicle and thence the cumulative impact (Eijk, et al, 2014). The modelling of emissions utilises vehicle characteristics (VSP - Vehicle Specific Power and/or EMEP/EEA - European Monitoring and Evaluation Programme/ European Environment Agency) and network characteristics combined (Fontes et. al., 2015).

Reviews of models used in studies have demonstrated that $60 \%$ of all modelling focuses on road modelling while only $30 \%$ of studies have combined road modelling with emissions modelling (Fontes, et al, 2015; Abou-Senna et al., 2013; Boriboonsomsin and Barth, 2008). This still shows a major gap in evaluating the impact on environment and public health in the design development process for roads and intersections despite the background of growing concern evidenced by the published policies for clean air and public health. $70 \%$ of all road modelling applications to date has been using micro-simulation models with emissions models. The microsimulation models vissim and paramics have been by far the preferred packages [by about $40 \%$ of all models] (Abou-Senna et al, 2013). From the reported studies, majority of these studies (70\%) have used average speed emission modelling (Dias et al., 2014; Bandeira et al., 2011; Borrego et al., 2004; Gulliver and Briggs, 2005; Mensink and Cosemans, 2008; Mumovic et al., 2006; Namdeo et al., 2002) while remaining studies used instantaneous emission modelling (Amirjamshidi et al., 2013; Misra et al., 2013).

\section{Lessons Learned and Approach to Robust Computational Analysis Using Integrated Modelling}

The use of transport modelling and emissions modelling studies analysed how combined microsimulation tools assess the environmental impacts of road traffic and the conclusion is that there are significant lessons to be learned. One of which is that the use of ASM does not fully replicate traffic operations on a congested network. On a congested network, the speed variability is significant along congested and uncongested parts of network; applications that link models have yet to be explored as there are concerns over compatibility of outputs from transport models to emissions models; and it is also acknowledged that for intersections such as the roundabout form leads to a number of underestimations of operations. The acceleration and deceleration which are not truly represented in models, at time stamped geo-spacing, would grossly underestimate emissions (Fontes et. al., 2015).

A number of other issues arises from modelling of traffic are:

1) Quality and Depth of Data:

a. Vehicle categories not identified through surveys. proportion of cars (general-purpose) vehicles, Light Goods Vehicles (LGV) and Heavy Goods Vehicles (HGV) which have different emissions would result in significant flaw in the modelling of current and future emissions;

b. VSP or EMEP/EEA not known for vehicles: engine sizes and types (Euro Norms i.e. Euro 6 engine, etc) not known creates a significant miscalculation of emissions from real life or modelled scenario;

2) Use of Average Speed Model: underestimates acceleration and deceleration patterns, therefore grossly underestimating emissions;

3) Traffic operations at congested conditions: Traffic re-routing due to improved road intersections or other traffic management interventions would result in re-assignment (traffic route changes). Without a re-assignment modelling technique, the modelled results for forecast years would not be realistic; and

4) Model Status: Calibration and validation of the models to replicate current operations before future forecasts are conducted.

This study therefore is based on a developed methodology, built further onto published material, to rectify issues in current approaches and produce a robust modelling framework with the allowance of computational abilities to evaluate emissions. To test the methodology, a case study of a roundabout intersection is conducted to demonstrate good practice the principles of which can be adopted for future studies.

\section{Analytical Approach for Computational Modelling Framework}

\section{Objectives}

The objective is to establish a coherent approach to provide robust evidence-based platform for emissions impact on public health that will support local and municipal authorities, as well as governmental organisations. There is a significant role for technologically advanced modelling tools to contribute towards reducing vehicle emissions and improving local air quality for public health and environment. Key opportunities for this will come through structured data fed into strategic models to analyse route choice. The route choice would need to be fed into advanced modelling techniques such as micro-simulation for vehicle routing and control functions to develop a more coherent approach to design our transport network. Linking micro-simulation models to environmental emissions modelling will enable true reflection of emissions analysis. Finally, representation of emissions in Geo-spatial manner to understand extend of influence of design options is key in facilitating improved public health. Geo-spatial representation will demonstrate impacts 
of the interventions which may be directly influencing vehicles, users, or indirectly in that they facilitate strategic changes in the network as well as influence on people in close proximity.

\section{Modelling and Analysis Approach}

In response to identified gaps and lessons learned so far, an approach of modelling and analysis is developed through a step-wise, three-tier computational analysis method using a series of technological software packages. The methodological approach framework is illustrated in Figure 1.

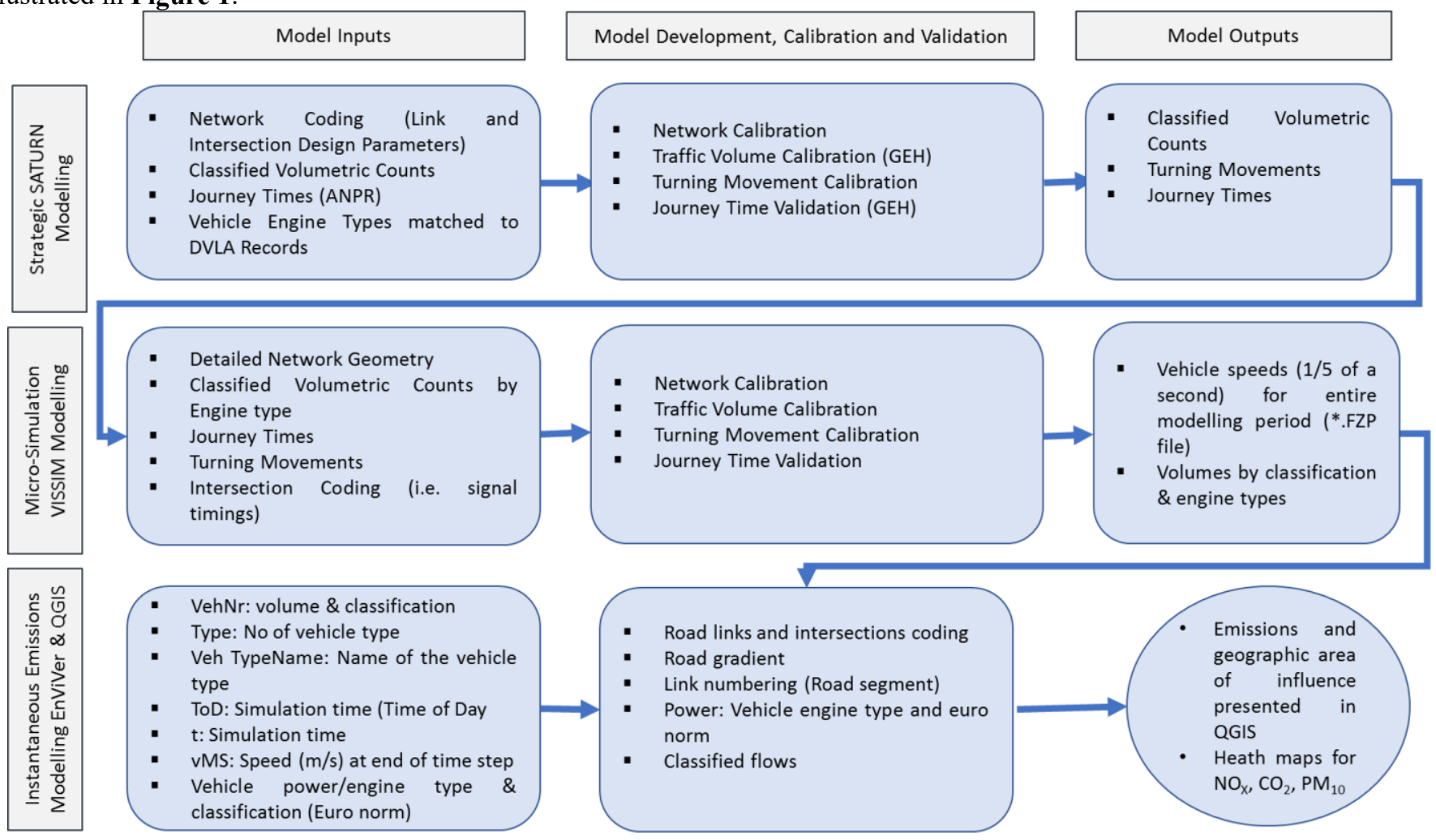

Figure 1 Modelling Framework

\section{Case Study}

The case study is selected for a congested urban road intersection which is currently in the form of a roundabout. The intersection is located on the A46 Cold Ashton road, a 7.2 KM predominantly single carriageway between Cold Ashton and M4 J18 motorway junction in the South West of England. The intersection is located at the cross-roads of A420 and A46, an at-grade roundabout with single lane entries and short flared approaches to the junction. The A46/A420 roundabout is observed to be the main source of congestion along the route presenting significant queuing, delays and journey time reliability issues along the corridor, Figure 2 Illustrates the location of the intersection.

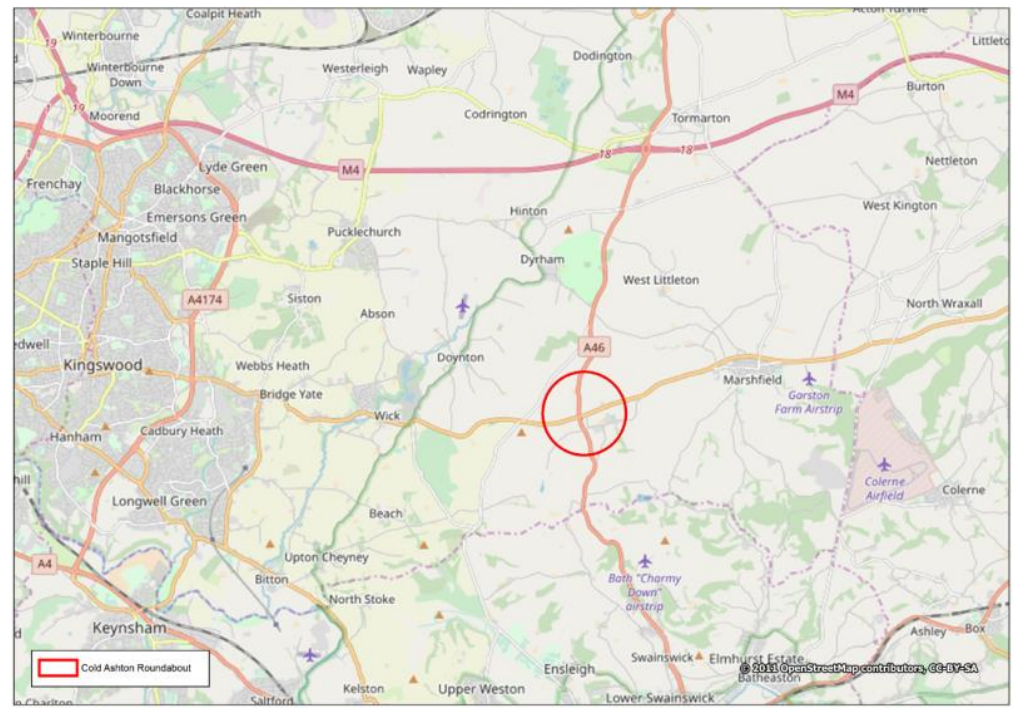

Figure 2 Location of the Intersection 


\section{Data Collection}

To analyse emissions for a typical weekday, a survey design is conducted, and data was collected. The data was collection was done at a neutral time of the year, selected as October 2018 where traffic patterns are known to represent a typical day with schools open. The data collection method is designed to measure vehicular movement for each 60 seconds period for classified volumetric count and time-stamped geo-referenced location of vehicles using Automatic Number Plate Registration (ANPR) method. Thus, the data which was collected comprise:

1) Classified Turning Counts: A46/A420 junction classified turning counts for 12-hour period (0700-1900) for seven days (using ANPR Cameras). Each vehicle record is linked to DVLA (Driver and Vehicle Licensing Agency) records of engine types and Euro norms for accurate classification of each vehicle's emissions;

2) Classified Volumetric Counts: 14 days of volumetric counts along the A46 and A420 Roads; and

3) Journey Time: survey along the A46 using ANPR cameras: The journey time route is conducted for north and south bound flows and timing points were identified to produce accurate timings for key road segments.

The data collection locations are illustrated in Figure 3.

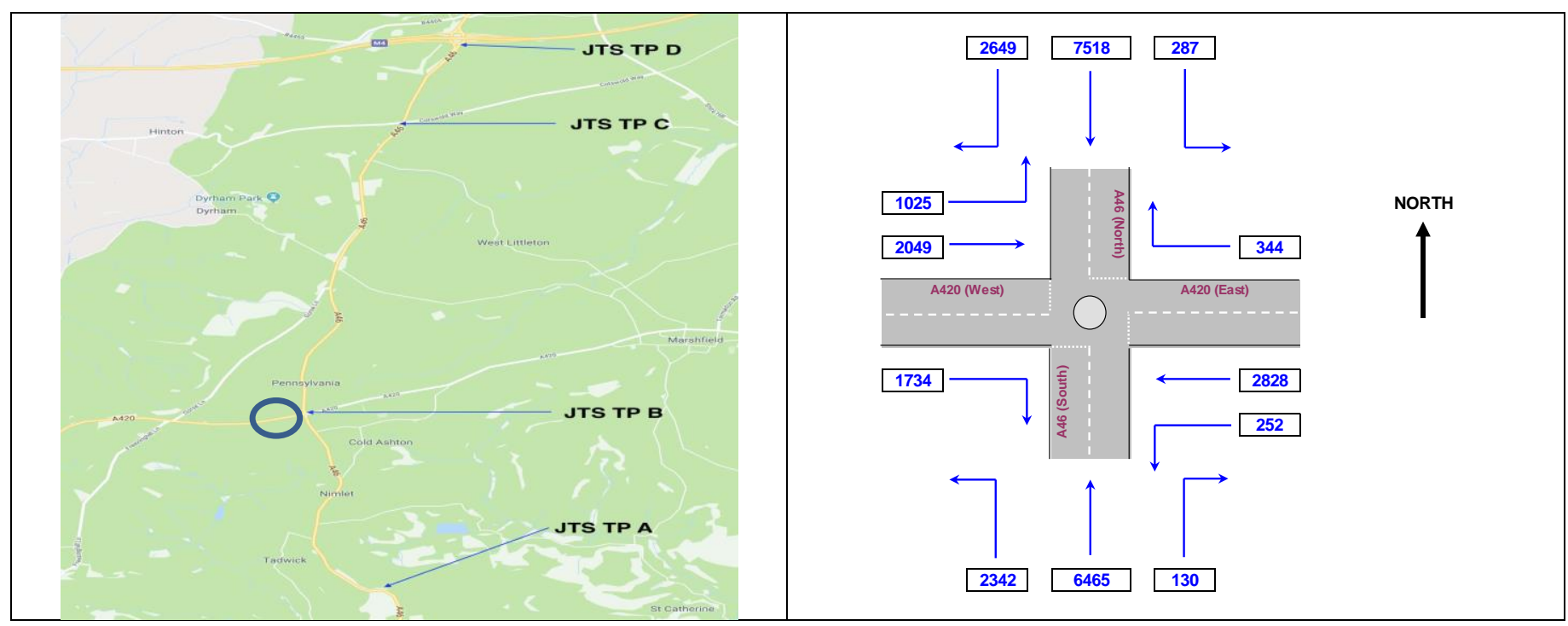

Figure 3 Data Collection Locations

Following the data collection, the next steps for computational analysis is based on:

1) Development of a strategic model to assess impact of existing operations and assist in design development through understanding of traffic re-assignment (route changes due to improved operations) due to proposed improvement options;

2) Utilising re-assignment of traffic for design options compared to existing operations by using micro-simulation modelling to generate time-stamped instantaneous emission modelling in EnViVer software; and

3) Mapping of computational analysis in QGIS to evaluate impact of emissions on the public.

Strategic Modelling: The road intersection operates as part of a wider route network and any interventions at a congested location has the potential to impact on that wider transportation network by drivers changing routes for their Origin-Destination movements. To understand such changes, a wider area model needs to be utilised to identify Area of Influence (AoI) for any changes in network operations. This is possible through use of a strategic Model, in this case using Simulation and Assignment of Traffic in Urban Road Network (SATURN) to evaluate potential change in flow percentages along the road network as a result of testing design options (Ferreira, et al 1981; Vliet, V. D., 2015). The model development process is guided by the principles of model development, calibration and validation which confirms suitability of the model to test options (DfT, 2014). A base year for 2018 was developed to cover the AM (0700-1000) Peak Period, Average Interpeak Period (1000-1600) and the PM peak periods (1600-1900). For each modelled period, calibration and validation of link counts is conducted through GEH statistics (GEH: Geoffrey Edward Havers). Using strategic modelling, traffic volumetric counts are calibrated and Journey times are validated using DfT criteria for Principles for Modelling and Forecasting (DfT, 2014). The model calibration and validation criteria of $85 \%$ is achieved. The calibration and validation statistics is illustrated in Table 1.

Table 1. Strategic Model Calibration and Validation Statistics

\begin{tabular}{l|c|c|c}
\hline \multicolumn{1}{c|}{ Model Calibration } & AM Peak Model & IP Peak Model & PM Peak Model \\
\hline Pass & 39 & 37 & 38 \\
\hline Fail & 0 & 3 & 2 \\
\hline
\end{tabular}




\begin{tabular}{l|c|c|c}
\hline \%age Pass & $100 \%$ & $93 \%$ & $95 \%$ \\
\hline \multicolumn{1}{c|}{ Link Validation } & AM Peak Model & IP Peak Model & PM Peak Model \\
\hline Pass & 10 & 9 & 9 \\
\hline Fail & 0 & 1 & 1 \\
\hline \%age Pass & $100 \%$ & $90 \%$ & $90 \%$ \\
\hline
\end{tabular}

The model has demonstrated acceptable calibration and validation levels with $85 \%$ or more of the modelled flows [individual locations] are achieved GEH criteria. The modelling criteria is introduced below (Vliet V. D., 2015; DfT, 2014)

$$
G E H=\sqrt{\frac{2(M-C)^{2}}{M+C}}
$$

Where $\mathrm{M}$ is the modelled flow and the $\mathrm{C}$ is the observed (data count). The GEH minimum requirement for acceptability is 5 (variance of 5\%) (DfT, 2014).

The SATURN Model coverage is illustrated in Figure 4.

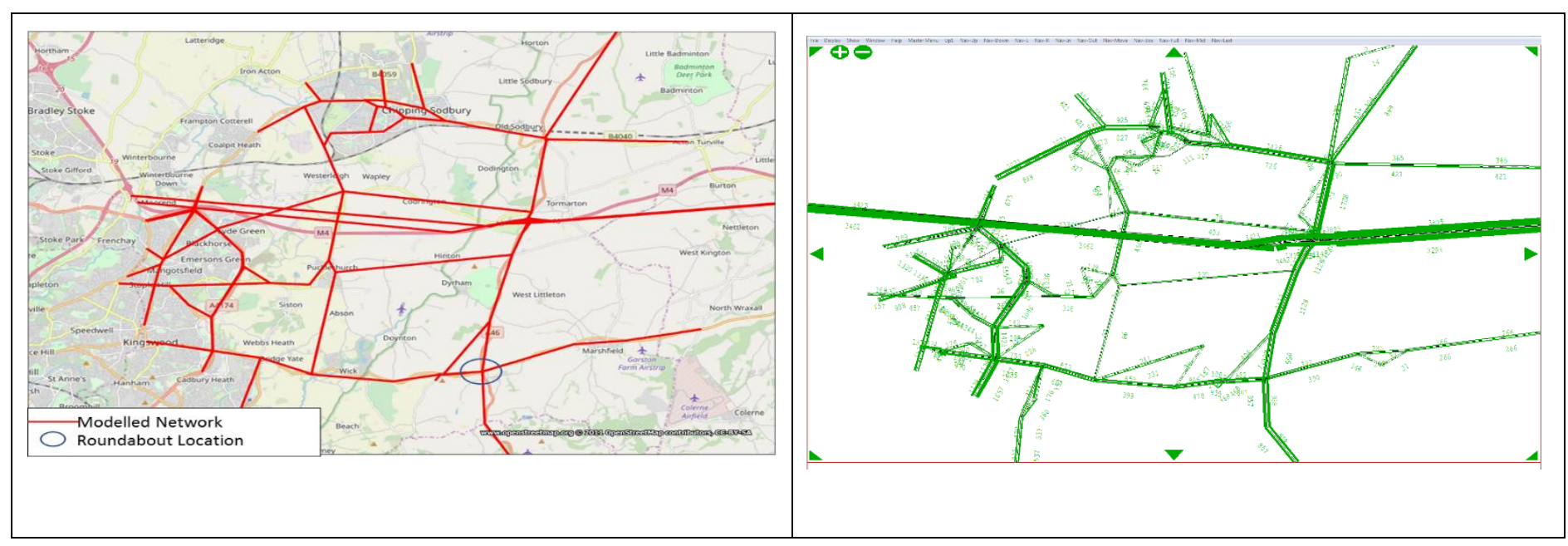

Figure 4 SATURN Network Coverage for Traffic Re-Assignment Evaluation \& Link Flows

The forecasted re-assigned traffic volumes and turning flows are introduced for the micro-simulation model future year (2021) options analysis at the next step.

Micro-Simulation Modelling: The development of the micro-simulation traffic model can be categorised in three main steps:

1) Model development: network development and traffic input for classified vehicle volumes, and for engine types/Euro norms; and

2) Calibration and validation of the model: The micro-simulation model calibration involves the driver behaviour calibration (gap acceptance, car-following, lane-changing, speed-flow curves and conflict parameters), and simulation resolution (time-steps analysis), turning movements and classified volumetric link flows. The validation step focuses on independent traffic volumes, journey times and averaged link speeds verification against obtained data.

3) Options testing: This stage involves comparative analysis of existing traffic network operations compared to the design development process with a view to minimise delays and queues, and improved speeds. The turning movements and volumes for intersections are obtained from the earlier step: SATURN re-assignment modelling.

The completion of the micro-simulation modelling has demonstrated achievement of calibration and validation criteria. The model has also generated time-stamped geo-spatial outputs of each vehicle using the model. Linking this to the DVLA vehicle and engine types, we have achieved real-time comparison of vehicle emissions for base operations and proposed design options. The visual timestamp geo-referenced location of vehicles within micro-simulation operations are introduced below in Figure $\mathbf{5}$ for base network and proposed design option. Options demonstrated significant queuing reduction for 2036-year assessment with the preferred option. 


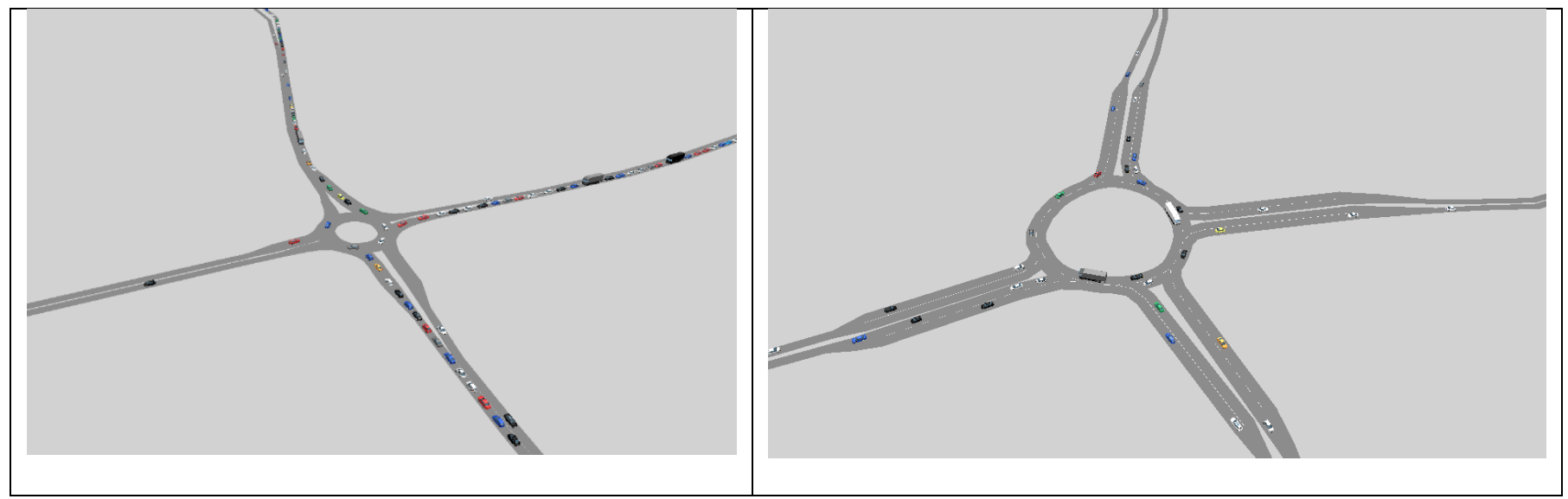

Figure 5 Visual representation of comparative queuing for base and prefeered option respectively.

Following the comparative analysis, the model development process concluded with the comparative analysis of base operations and proposed design option, optimised to produce minimum delays, queues and improved speeds on links. Typical comparative analysis of delay changes is presented in Figure 6.

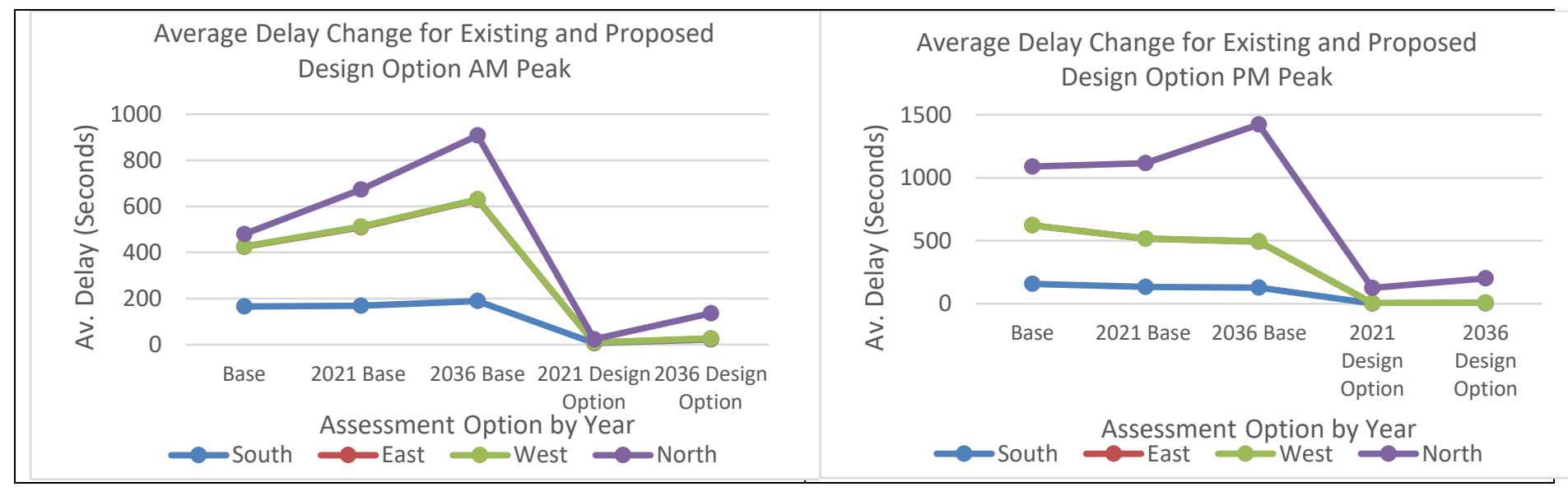

Figure 6 Comparative Analysis of Base and Final Optimised Option for Delay Analysis (For AM and PM Peak Periods)

Figure 6 clearly demonstrated that the development of the design option for 2021 and 2026 has reduced delays, improved journey times and speeds significantly compared to the based intersection for 2021 and 2026 operations for both AM and PM peak periods.

Through the design development process, the other tested options such as signal control also demonstrated some imrpvoement but still resulted in comparativelt long queues and delays. Thus, computational analysis informed the optimised option design development utilising DfT design standards (DfT, 2007) and selected the optimum design which is predicted to reduce delays, queues and increased the network speeds. The comparative options for base, intermediate signal control option, and optimised design for the intersection is illustrated in Figure 7 respectively.

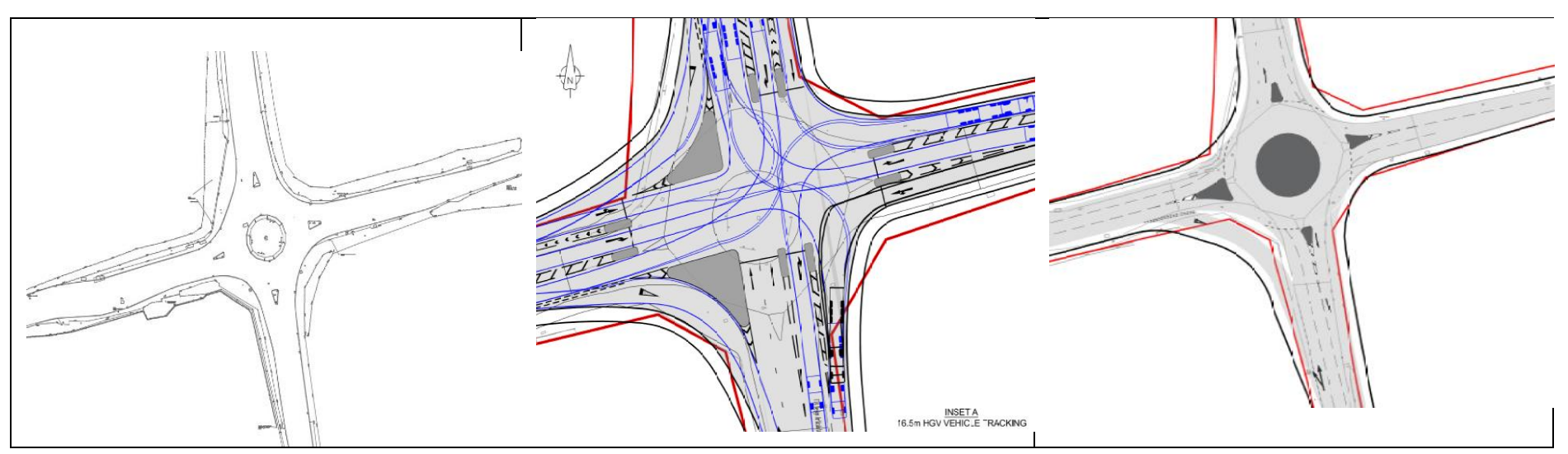

Figure 7 Comparative designs for existing and optimised highest performing intersections 
The outputs from the VISSIM model are time-stamped location of each vehicle in geo-referenced style with speed and delay at $1 / 5$ fraction of a second, for the entire duration of the simulated model period and for each vehicle. This utilises the *.FZP file format where a large file is produced for input into EnViVer software.

Environmental Modelling - EnViVer: is an instantaneous emissions model (IEM). Use of IEM provided more accurate representation emissions due to accurate modelling of acceleration and deceleration movements, and associated emissions is calculated. For this study, in addition to the specific traffic flows, speed samples with a time stamp for each vehicle (identified with a vehicle type tag) geo-referenced at $1 / 5$ of a second through the modelled period, the vehicle types, engine types/Euro norms for each vehicle type (general-purpose vehicles, LGV and HGV) has been imported for accurate modelling. The compilation of vehicle engine types is introduced in figure 8 below.

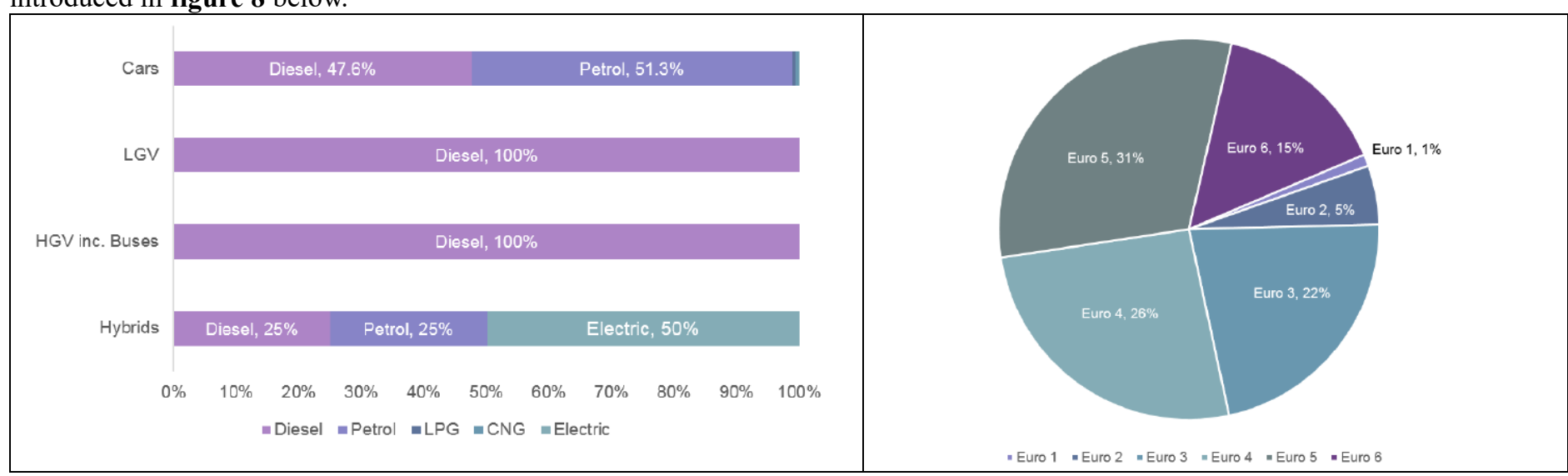

Figure 8 Vehicle Engine Types and Engine Norms for this study

Geographic Information Systems Integration of Results Presentation QGIS: QGIS is an open-source GIS application with advanced capabilities. Spatial Databases allow the storage of the geometries of records inside a Database as well as providing functionality for querying and retrieving the records using these Geometries (Ghandi, U., 2019). Given its open source nature it is a very popular application where queues, delays emissions can be mapped in a 'heat map style' approach.

Computational Analysis - Summary: Calibration and validation process applied for the data collected and estimated by the traffic model for the SATURN and VISSIM models. The outputs of micro-simulation model were used as inputs in the emission methodologies (engine powers and types). These methodologies were used to quantify the emissions amounts with high temporal and spatial resolution. The procedure follows the general rules defined in "Modelling framework" in the Modelling and Analysis section in figure 1.

Using real-world traffic data and advanced modelling techniques which are enabled through the very high processing powers to record vehicle modelling for every $1 / 5$ fraction of a second for the entire model periods each of which have been fully validated and audited. The most appropriate design interventions development for reducing vehicle emissions using simulation traffic models and instantaneous emissions models (IEM) are subsequently produced. These are based on validated real-world operations.

\section{Results and Discussion}

The results produced because of developed method framework and presented here will serve as a "proof of concept" for design development and computational approach within the context of international world to meet with the requirements of the World Health Organisation Policies.

\subsection{Traffic Analysis}

The first step of the adopted computational approach is to analyse traffic operations for 'base' (existing intersection layout) compared to the options development stage, leading to preferred option. The development of the preferred option layout has gone through a number of iterative computational analysis before arriving to the preferred layout. This analysis presents the comparative analysis of base and final preferred scheme.

The high-level traffic analysis computation has focused on comparison of total vehicles passing through the intersection, average speed of vehicles for the modelled network, total distance travelled for all vehicles, total travel time and delay, and total stopped delay. The results are summarised in Table 2 below: 


\begin{tabular}{l|l|c|c|c|c|c}
\hline $\begin{array}{l}\text { Computational } \\
\text { Analysis Field } \\
\text { (AM Peak) }\end{array}$ & Units & $\begin{array}{c}\mathbf{2 0 1 8} \\
\text { Base }\end{array}$ & $\begin{array}{c}\mathbf{2 0 2 1} \\
\text { Do Nothing }\end{array}$ & $\begin{array}{c}\mathbf{2 0 3 6} \\
\text { Do Nothing }\end{array}$ & $\begin{array}{c}\mathbf{2 0 2 1} \\
\text { Preferred } \\
\text { Scheme }\end{array}$ & $\begin{array}{c}\mathbf{2 0 3 6} \\
\text { Preferred } \\
\text { Scheme }\end{array}$ \\
\hline Vehicles Arrived & Vehicles & 7786 & 7792 & 7772 & 7786 & 7912 \\
\hline $\begin{array}{l}\text { Total Distance } \\
\text { Travelled }\end{array}$ & $\mathrm{KM}$ & 42166 & 43006 & 43271 & 42166 & 46191 \\
\hline Average Speed & $\mathrm{KM} / \mathrm{h}$ & 56 & 49 & 41 & 56 & 69 \\
\hline Total Travel Time & Hours & 753 & 945 & 1062 & 753 & 696 \\
\hline Total Delay & Hours & 245 & 398 & 512 & 245 & 239 \\
\hline Stopped Delay & Hours & 23 & 56 & 81 & 23 & 19 \\
\hline
\end{tabular}

From the analysis, the following has been deduced.

- The average network speed for the micro-simulation area has increased by $40.82 \%$ for 2021 analysis and $60.98 \%$ for 2036 analysis between the base and preferred option.

- Total Stopped delay has reduced by $66.07 \%$ for 2021 analysis and $70.37 \%$ for 2036 analysis between the base and preferred option.

- Total Junction Delay has reduced by $39.95 \%$ for 2021 analysis and $48.24 \%$ for 2036 analysis between the base and preferred option.

- Total queues reduced by $42 \%$ for 2021 analysis and 69\% for 2036 analysis between the base and preferred option.

The visual demonstration of the modelled network performance is illustrated in Figure 9 for base and preferred option results.

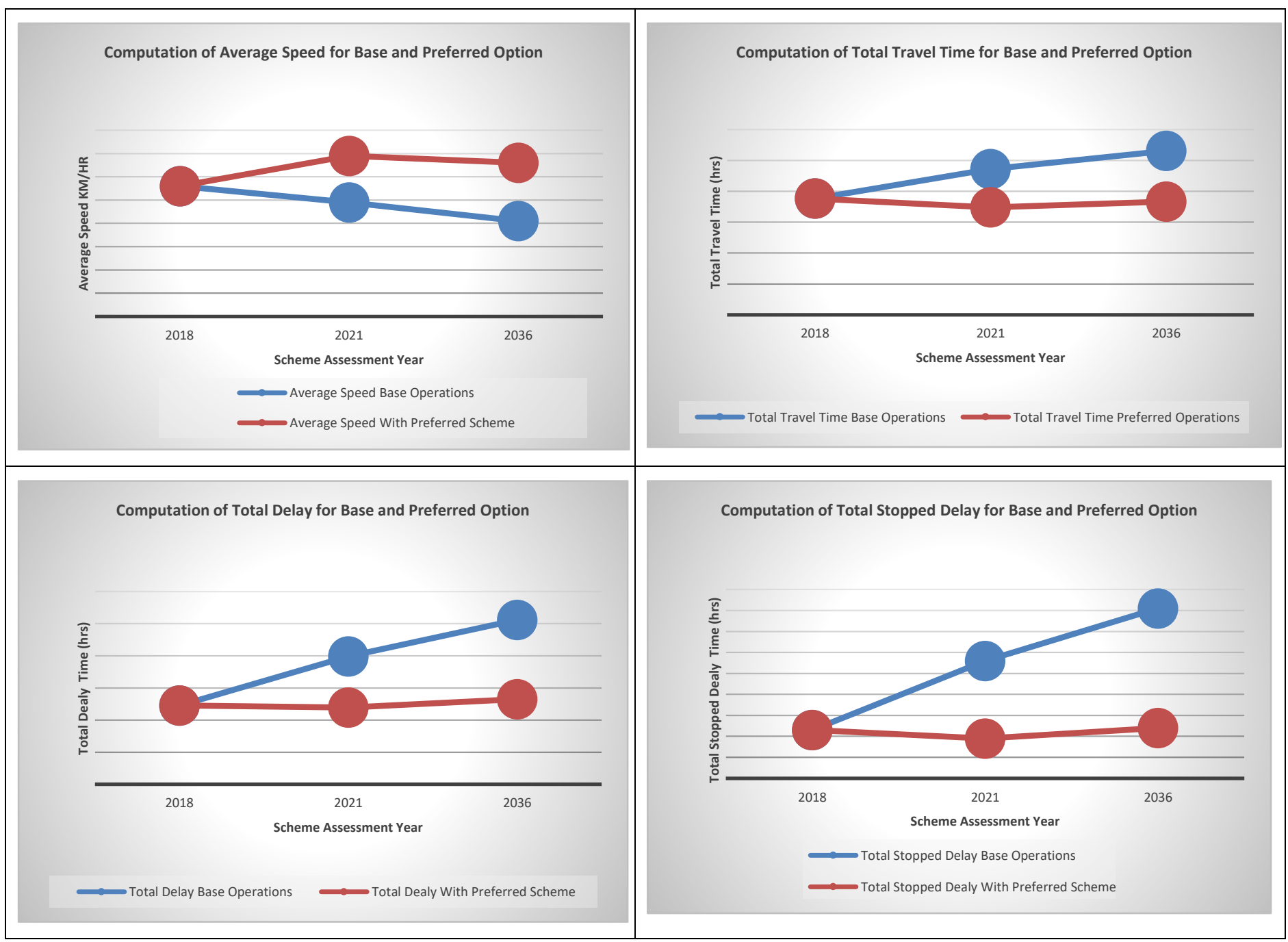

Figure 9 Computational analysis results for Base and preferrred option

\subsection{Emisions Analysis}


Similarly to the traffic analysis, a significant reduction in emissions have been achieved with the preferred scheme. The $\mathrm{CO}_{2}, \mathrm{NO}_{\mathrm{x}}$, and $\mathrm{PM}_{10}$ results have shown a systematic reduction from base operations for both 2021 and 2036 modelled assessment. The comparative analysis results are presented in Table 3 below.

Table 3 Comparative Change in Emissions for CO2, NOx PM $M_{10}$ Between Base and Preferred Option

\begin{tabular}{c|c|c|c|c|c}
\hline \multirow{2}{*}{ Pollutant } & Peak Hour & $\begin{array}{c}\text { 2021 DM } \\
\text { Change from 2017 } \\
\text { Base }\end{array}$ & $\begin{array}{c}\text { 2021 DS } \\
\text { Change from 2021 } \\
\text { DM }\end{array}$ & $\begin{array}{c}\text { 2036 DM } \\
\text { Change from 2021 } \\
\text { DM }\end{array}$ & $\begin{array}{c}\text { 2036 DS } \\
\text { Change from } \\
\text { 2036 DM }\end{array}$ \\
\hline \multirow{2}{*}{$\mathrm{CO}_{2}$} & $08: 00-09: 00$ & $3.74 \%$ & $-13.38 \%$ & $15.38 \%$ & $-21.97 \%$ \\
\cline { 2 - 6 } & $17: 00-18: 00$ & $4.00 \%$ & $-16.95 \%$ & $19.24 \%$ & $-32.30 \%$ \\
\hline \multirow{2}{*}{$\mathrm{NO}_{x}$} & $08: 00-09: 00$ & $3.77 \%$ & $-14.55 \%$ & $14.17 \%$ & $-34.75 \%$ \\
\cline { 2 - 6 } & $17: 00-18: 00$ & $2.84 \%$ & $-15.47 \%$ & $18.84 \%$ & $-25.61 \%$ \\
\hline \multirow{2}{*}{$\mathrm{PM}_{10}$} & $08: 00-09: 00$ & $4.55 \%$ & $-14.38 \%$ & $15.81 \%$ & $-24.04 \%$ \\
\cline { 2 - 6 } & $17: 00-18: 00$ & $3.42 \%$ & $-14.69 \%$ & $18.22 \%$ & $-26.31 \%$ \\
\hline
\end{tabular}

The results have demomnstrated that there would be a 13-16\% reduction in CO2, NOx and $\mathrm{PM}_{10}$ for 2021, and 21-34\% redcution for 2036 between the existing (base) layout and preferred intersection layout (see figure 7).

The results have demonstarated more accurate representation of the emissions as a result of using 'enhanced' detail of time-step analysis ( $1 / 5$ steps per second for each vehicle modelled) and geo-referenced movement of each vehicle through the network. This approach has provided significantly improved granularity of emissions on the network. The adopted QGIS visulisation has demonstrated the extnd of reduftin in emissions, whereby bringing emission levels to WHO and EU policies. The geo-referenced comaprative emissions is presented in Figure 10 below.

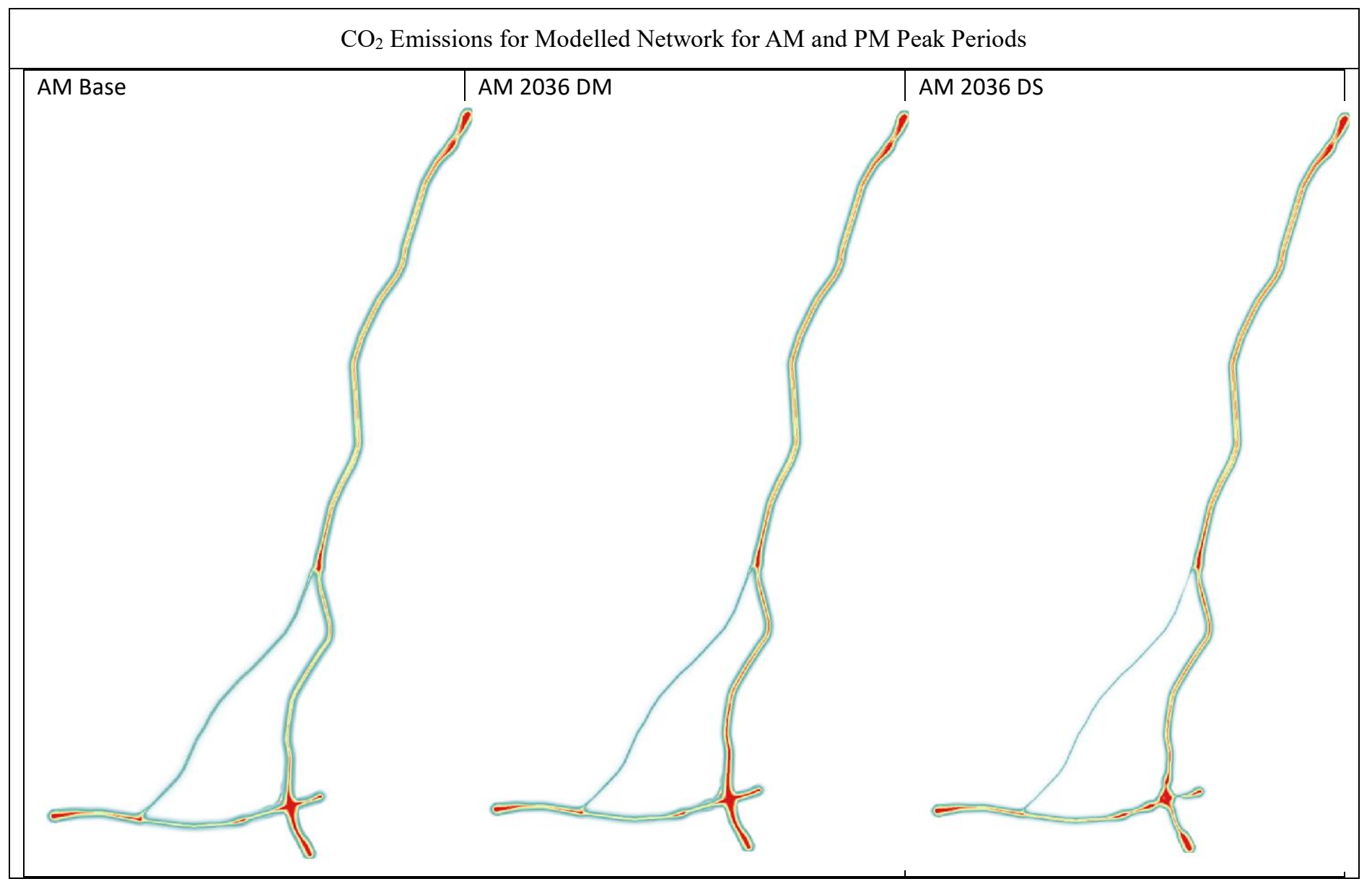




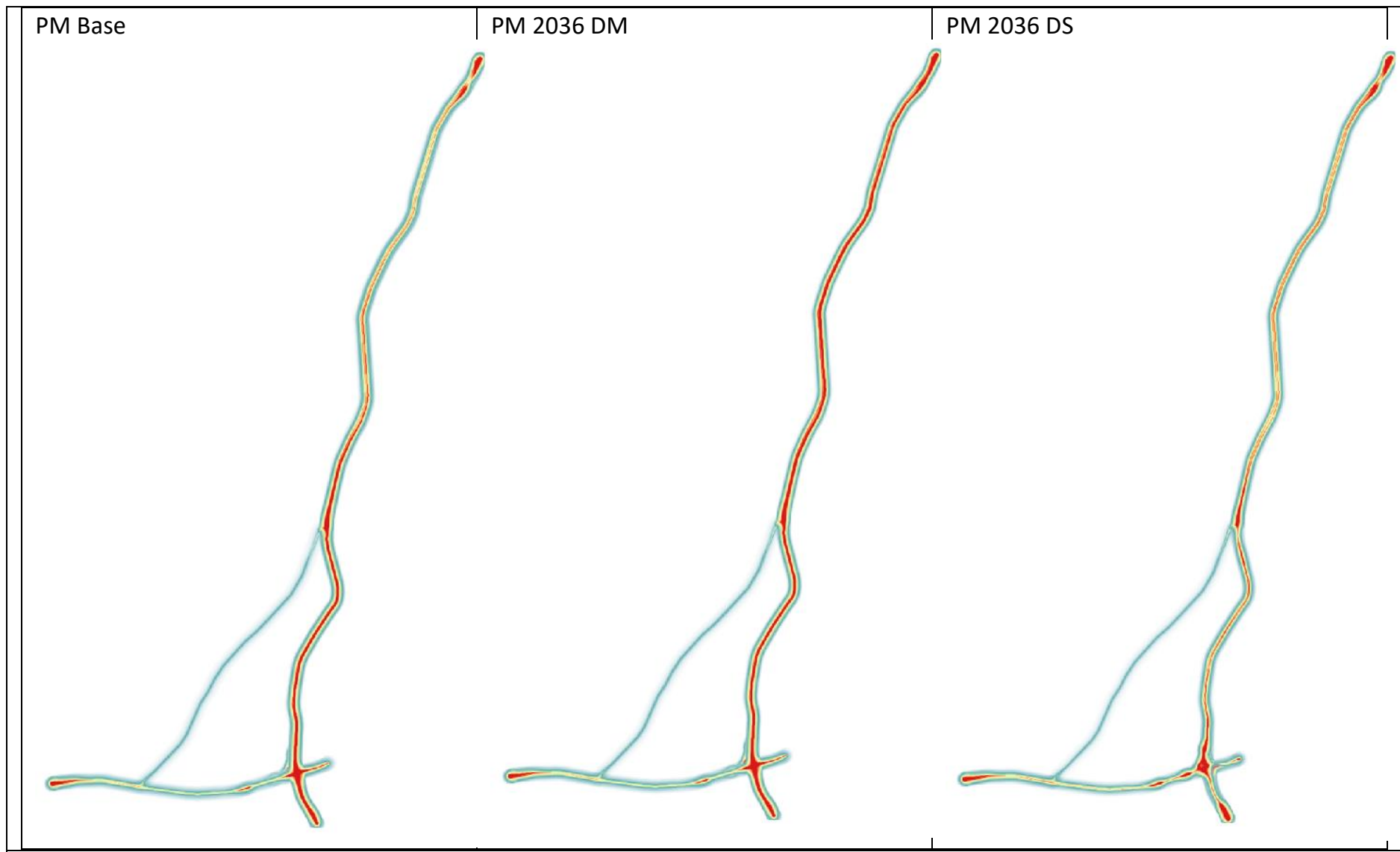

NOx Emissions for Modelled Network for AM and PM Peak Periods

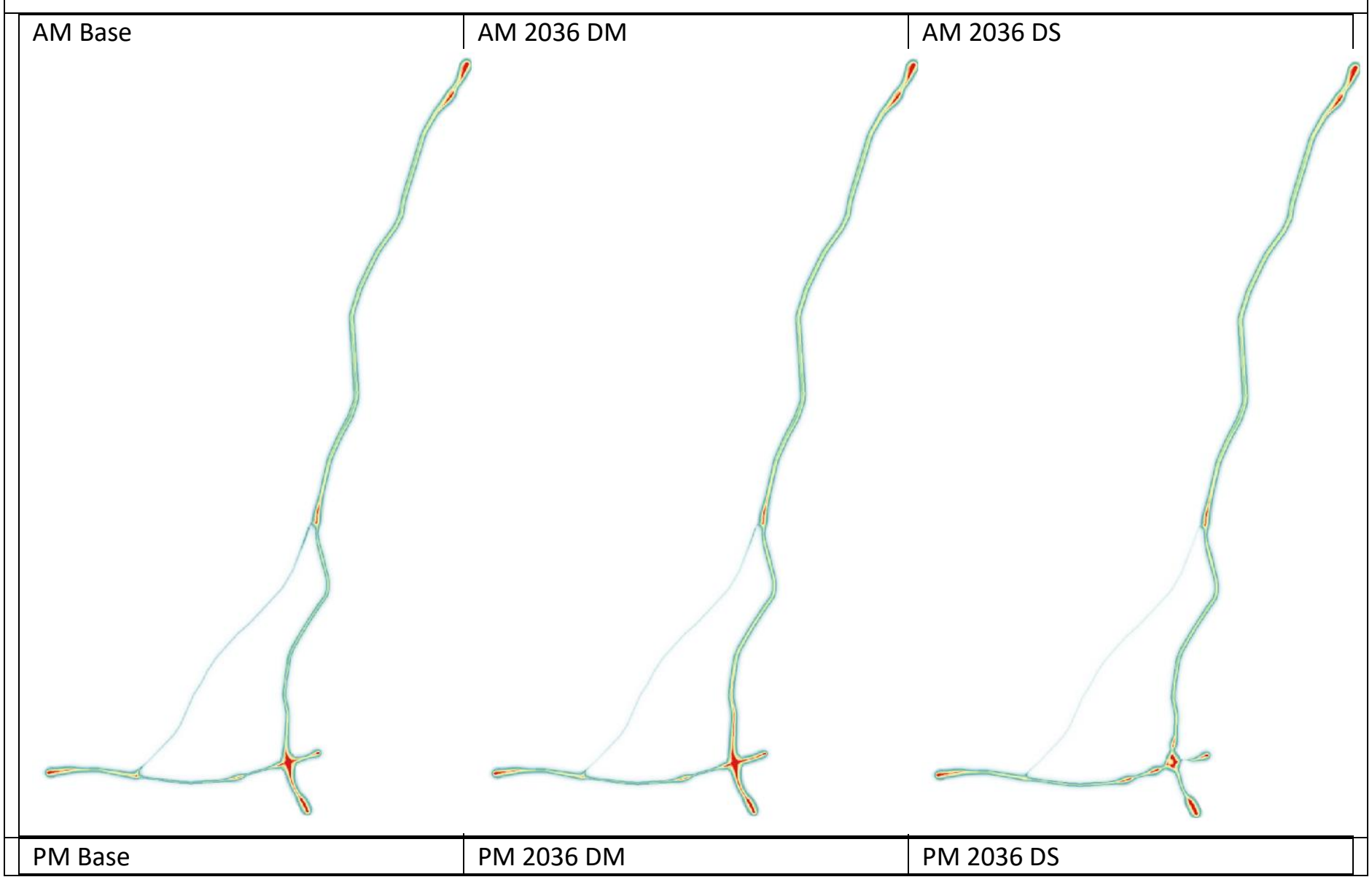




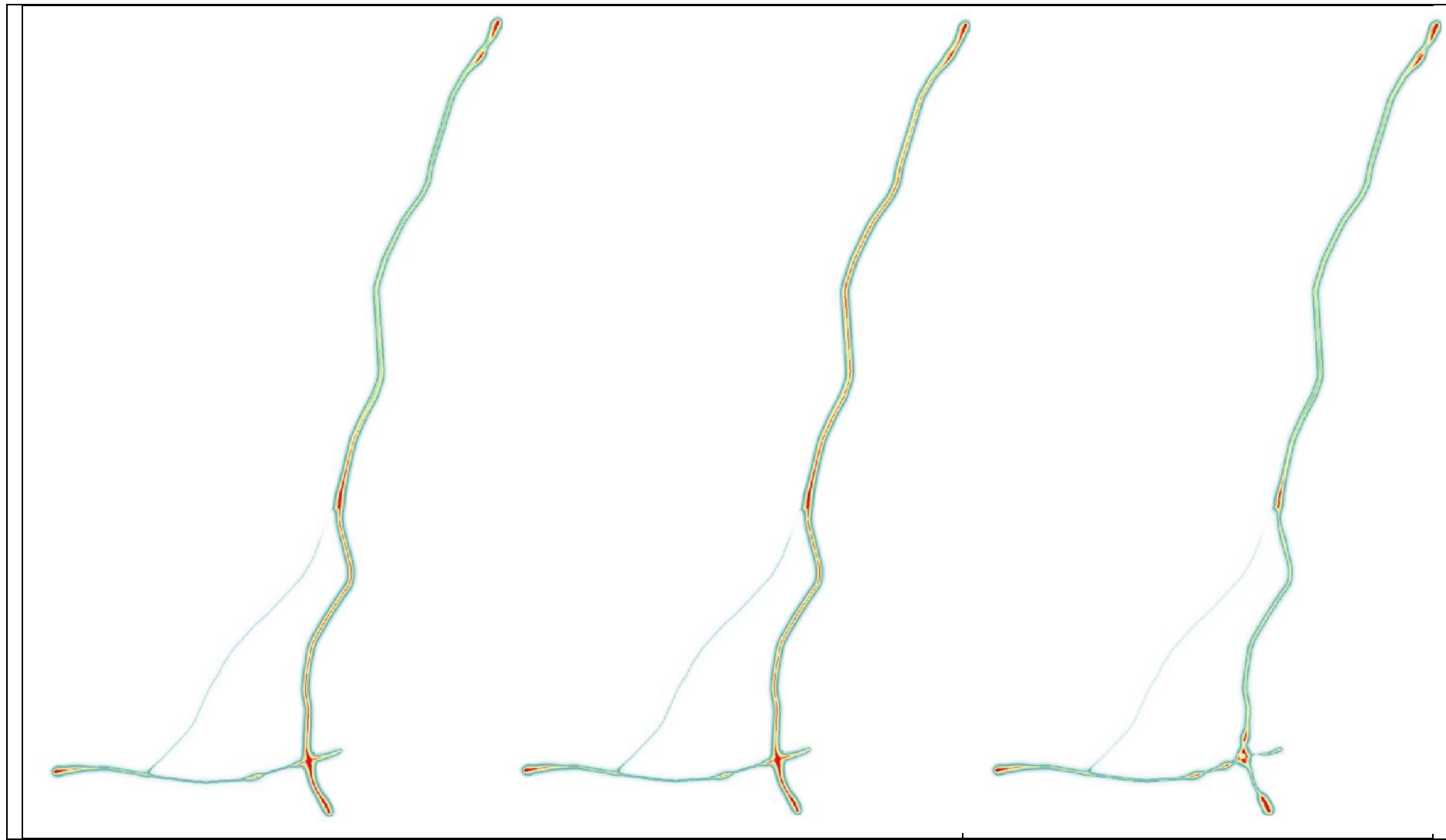

$\mathrm{PM}_{10}$ Emissions for Modelled Network for AM and PM Peak Periods

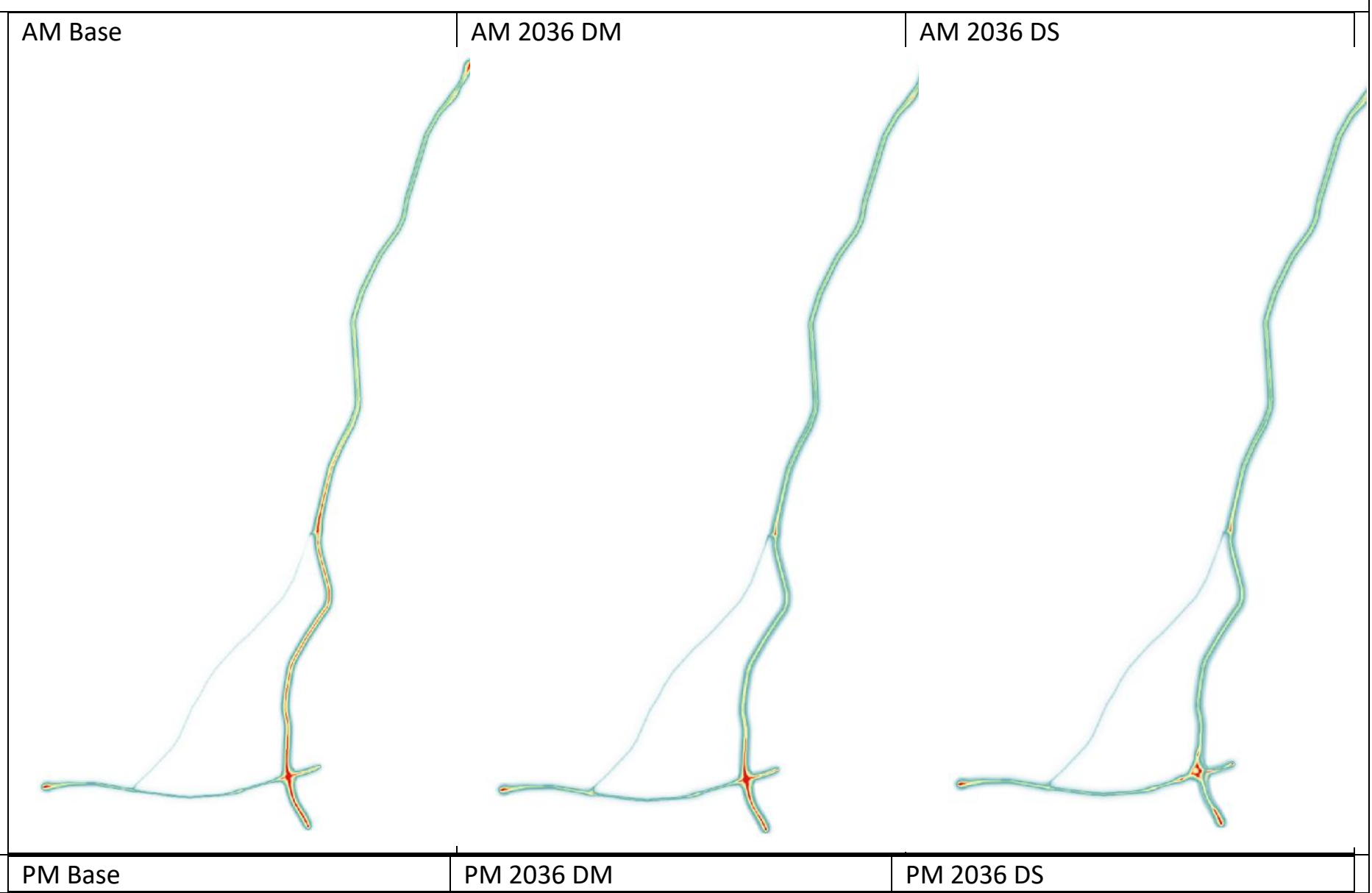




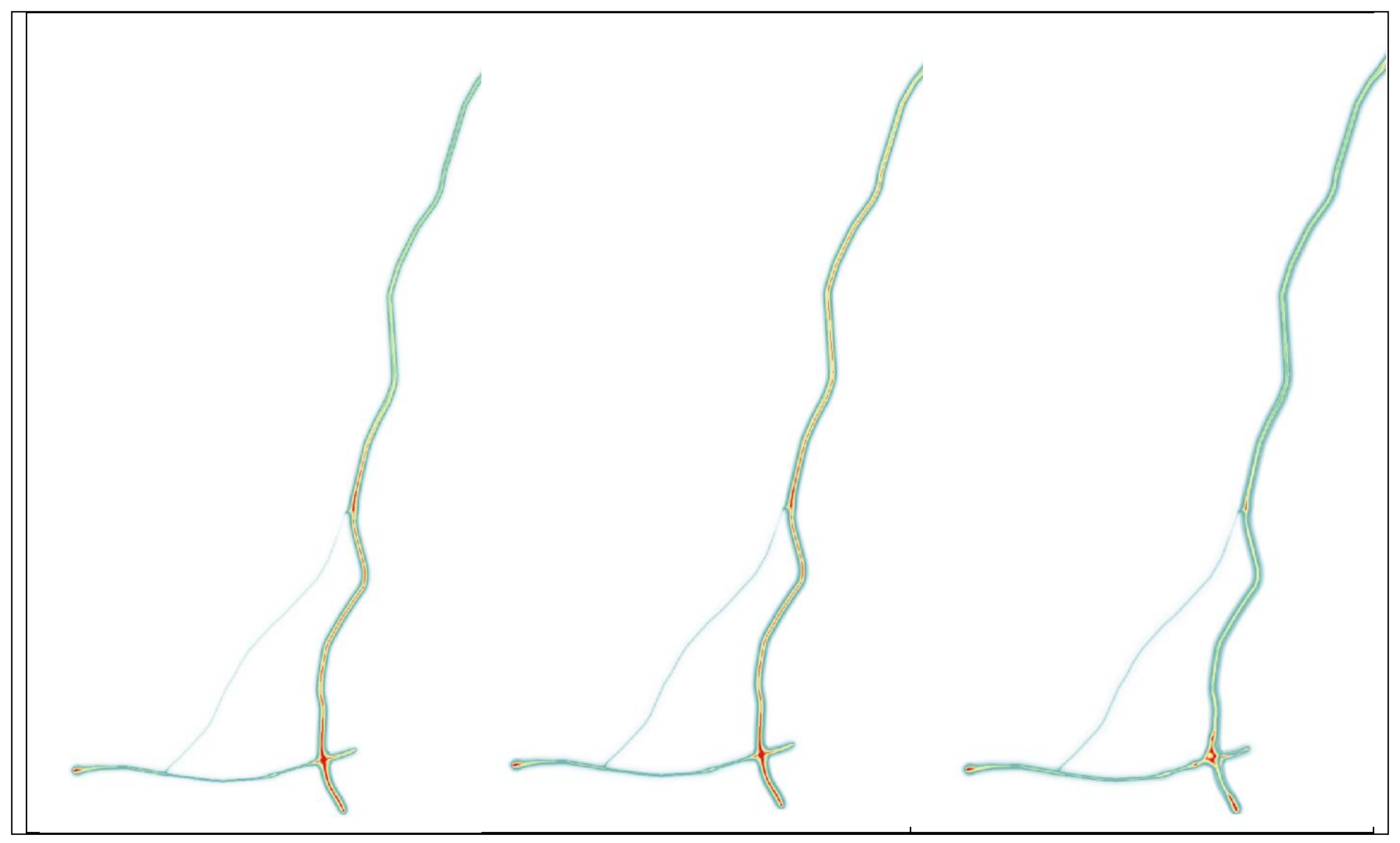

Figure 10 Geo-referenced location of emissions

The goe-referenced emissions have reduced significantly reduced whereby the highest emissions were limited to a very narrow band within the intersection where without the scheme the queuing would result in high emissions along the northern arm of the intersection.

\section{Conclusions and Recommendations}

\section{Conclusions}

This paper has demonstrated how a combination of technologically advanced software packages can be utilised to inform emissions and associated public health and adherence to environmental policies. Paper also presented an extensive review of applied methods in road traffic impact on emissions. This paper has advanced the use of current applications to achieve accuracy when comparing design options and link those to the environmental impact and public health policies which are the ultimate objective of conducting such analysis. It has also extended the knowledge base to inform the environmental impact and public health policies which are the ultimate objective of conducting such analysis. While doing so, this paper has analysed previously identified modelling problems currently faced and introduced a sophisticated modelling approach and a new framework where can now be adopted to provide robust analysis of emissions, beyond and that produced by an "averaged" interpretation.

The developed methodology framework identifies not only 'what' data, but also specifics of data such as collation of vehicle types (general-purpose vehicles: cars, Heavy Goods Vehicles and Light Goods Vehicles) which have different engine powers and emissions. The approach also advanced data methods by utilising ANPR cameras to obtain vehicle registrations and link to government's portal, DVLA, to ensure each vehicle's engine norm (Euro standard) is captured. This has significantly enhanced the accuracy of the computations.

The use of a two-tiered approach in traffic modelling advances the previously adopted modelling methodology by capturing any re-assignment effect of road network improvement at tier one model. This can be linked to micro-simulation tool VISSIM to capture accurate representation of each vehicle emissions.

The quality of input into emissions software, EnViVer using time-stamped and geo-referenced vehicle movements at $1 / 5$ of a second informed Instantaneous Emissions Model with high accuracy of emitted gases and particles. This has significantly improved the previously applied IEM approaches by achieving significantly greater accuracy. Finally, the use of QGIS approach has linked the emissions to geo-referencing where accurate understanding of extent of problems are identified and policy objectives are informed. 
The case study illustration which was based on a microsimulation traffic model (VISSIM) and emission methodologies (vehicle power and Eurpoean engine norms) were linked to EnViVer and QGIS for geo-referenced illustration of emissions in a 'heath map' format. This specific methodology applied to a congested intersection with known congestion and environmental problems is a true reflection of very many densely populated medium-sized European Cities. The approach adopted compared the existing traffic operations without intersection improvement to options developed. A clear pattern of reduction in $\mathrm{NO}, \mathrm{CO}_{2}$ and Particulate Matter reduction is observed.

The adopted process has informed the selection of "right" intersection design by informing the change in the accurate emissions computations. The findings informed that:

- Total Stopped delay has reduced by a range of $66-70 \%$ from base to preferred intersection design layout;

- Improvement in overall network speed by $40-60 \%$, which informs emission calculations;

- Reduction in overall queuing by a range of $42-69 \%$.

The emissions calculations have informed that

- NOx emissions have reduced by a range of $14-34 \%$ from base to preferred intersection design layout;

- $\mathrm{CO}_{2}$ emissions has reduced by a range of $13-32 \%$ from base to preferred intersection design layout;

- $\mathrm{PM}_{10}$ emissions has reduced by a range of $14-26 \%$ from base to preferred intersection design layout.

Therefore, a non-linear relationship is demonstrated between increase in overall speed and reduction in emissions. A Similar relationship is observed by reduction in delays (or opposite relationship with increase in speeds) and emissions. Hence, the use of technological tools, linked together, presents the best practice which should be adopted. This approach advances current methodologies to perform more accurate analysis of traffic performance and emissions in line with the WHO and EC policies.

\section{Recommendations}

The results have demonstrated that linking computational ability for micro-simulation modelling of road intersections to environmental package has been successful in analysis of network operations and emissions. The 'methodology framework' has added significant knowledge on published material for more accurate coding and evaluation of emissions for public health. The key sequence to be applied are 1) modelling software to test emissions and inform air quality thresholds using a series of software tools in an integrated manner, 2) enable prediction of alternative intersection designs supporting air quality and 3) to produce functions for intersection operational parameters with NOX, CO2 and PM savings.

To minimise errors in emissions calculations, the following must be adhered:

- Data must be linked to government sources for engine sizes and types information before modelling starts;

- Route choice must be analysed through wider area model;

- Micro-simulation model must run with small time steps (i.e. in this case 1/5 of a second) to correctly examine acceleration and deceleration of vehicle and engine types;

- $\quad$ Road and junction coding must be calibrated to local geometry as well as utilising correct gradient for roads; and

- Geo-representation using GIS to inform policies should be a uniform approach.

The methodology framework utilising technologically advanced modelling tools has enabled design development of future intersection operation to minimise $\mathrm{NO}_{\mathrm{X}}, \mathrm{CO}_{2}$ and $\mathrm{PM}$. This modelling framework is recommended to minimise road delays and queuing based emissions formulation, enabling adoption for similar studies in future to comply with World Health Organisation Policies.

\section{Acknowledge}

This paper is based on two real projects which is funded by two separate streams of research: 1) Highways England funded A46 study to develop operational alternatives to existing, congested location where queues, delays, journey times and emissions were found significant; and 2) Coopoerative Intelligent Transport Systems to reduce Vehicle Emissions: Stage C 'Evaluation and Appraisal' which has enabled use of EnViVer software. Author acknowledge the data and software provision to be able to complete this study.

\section{References}

Amirjamshidi, G., Mostafa, T.S., Misra, A., Roorda, M.J. Integrated model for microsimulating vehicle emissions, pollutant dispersion and population exposure. Transp. Res. Part D Transp. Environ. 2013. 18, 16-24.

Abou-Senna, H., Radwan, E., Westerlund, K., Cooper, C.D. Using a traffic simulation model (VISSIM) with an emissions model (MOVES) to predict emissions from vehicles on a limited-access highway. J. Air Waste Manag. Assoc. 2013.63 (7), 819-831.

Bandeira, J.M., Coelho, M.C., Sá, M.E., Tavares, R., Corrego, C.. Impact of land use on urban mobility patterns, emissions and air quality in a Portuguese medium-sized city. Sci. Total Environ. 2011. 409 (6), 1154-1163.

Bandeira, J.M., Almeida, T.G., Khattak, A., Rouphail, N.M., Coelho, M.C.. Generating emissions information for route selection Experimental monitoring and routes characterization. J. Intell. Transp. Sys. 2013. 7 (1), 1-15.

Boriboonsomsin, K., Barth, M. Impacts of freeway high-occupancy vehicle lane configuration on vehicle emissions. Transp. Res. Part D Transp. Environ. 2008. 13 (2), 112-125.

Borrego, C., Tchepel, O., Salmim, L., Amorim, J., Costa, A.M., Janko, J. Integrated modelling of road traffic emissions: application to Lisbon air quality management. Cybernet. Syst. Int. J. 2004.35 (5-6), 535-548. 
Dias, D., Amorim, J.H., Sá, E., Borrego, C., Fontes, T., Fernandes, P., Pereira, S.R., Bandeira, J., Coelho, M.C., \& Tchepel, O. Impact of road transport on urban air quality: GIS and GPS as a support for a modeling framework, GIS. Ostrava 2014, 27-29/01, Ostrava.

Department for Transport (DfT). Transport Advisory Unit M1: Principles of Modelling and Forecasting (https://assets.publishing.service.gov.uk/government/uploads/system/uploads/attachment data/file/427118/webtag-tag-unit-m1-1principles-of-modelling-and-forecasting.pdf). 2014. (accessed on 25/06/2018).

Department for Transport (DfT). Geometric Design of Roundabouts. 2007. Design Manual for Roads and Bridges (DMRB), Volume 6 Road Geometry, Section 2 Junctions, Part 3 TD16/07. Highways England, UK.

European Commission. Clean Air (https://eur-lex.europa.eu/legal-content/EN/TXT/PDF/?uri=CELEX:32008L0050\&from=EN), 2008. (accessed on 31/05/2018).

European Environment Agency (EEA). Air Quality in Europe - 2-18 Report. Luxembourg: Publications Office of the European Union, 2018. ISSN 1977-8449. doi: 10.2800/777411

Eijk, A., Ligterink, N., and Inanc S., EnViVer 4.0 Pro and Enterprise Manual. 2014.

Ferreira, L.J.A., Hall, M.D. and van Vliet, D. SATURN - A User's Manual. AMDAHL V7 Version. Working Paper. Institute of Transport Studies, University of Leeds, Leeds, UK. Working Paper 146. 1981.

Fontes T., Pereira, P., Fernandes, J . M., Bandeira, J. M., Coelho, M. C. How to combine different microsimulation tools to assess the environmental impact of road traffic? Lessons and direction. 2015. Transportation Research Part D. 34 (2015) 293-306.

Gulliver, J., Briggs, D. Time-space modeling of journey-time exposure to traffic-related air pollution using GIS. Environ. Res. 2005. 97 (1), 10-25.

Mensink, C., Cosemans, G. From traffic flow simulations to pollutant concentrations in street canyons and backyards. Environ. Model. Softw. 2008. 23 (3), 288-295.

Misra, A., Roorda, M., MacLean, H.L. An integrated modelling approach to estimate urban traffic emissions. Atmos. Environ. 2013. 73, 81-91.

Mumovic, D., Crowther, J.M., Stevanovic, Z. Integrated air quality modelling for a designated air quality management area in Glasgow. Build. Environ. 2006. 41 (12), 1703-1712.

Namdeo, A.K., Mitchell, G., Dixon, R.. TEMMS: an integrated package for modelling and mapping urban traffic emissions and air quality. Environ. Model. Softw. 2002. 17 (2), 177-188.

Project Report.Corporative Intelligent Transport Systems to Reduce Vehicle Emissions: Stage C: Evaluation and Appraisal. 2018.

PTV Vision, VISSIM 5.30-05 User Manual, 2011.

Gandhi, Ujaval. QGIS Tutorials and Tips. https://www.qgistutorials.com/en/. (accessed on 25/06/2019.).

Van Vliet, D. SATURN Travel Demand Forecasting Software User's Manual. 2015, Version 11.3, Section 15.6, http://www.saturnsoftware.co.uk/saturnmanual/pdfs/Section\%2015.pdf. (Accessed 25/06/2019)

World Health Organisation (WHO). Health Effects of Transport-related Air Pollution. WHO Publ., Copenhagen. http://www.euro.who.int/_data/assets/pdf_file/0013/91102/E88772.pdf (accessed on 24/06/2019.). 2006. 